\title{
The effects of rheumatoid arthritis on Cypriot recreational athletes
}

\section{A reumatoid artritisz hatása a ciprusi szabadidős sportolókra}

\author{
Stephen Nicolaou, Efstathios Christodoulides
}

University of Central Lancashire Cyprus, School of Science, Sports and Exercise Sciences

\begin{abstract}
Introduction: Recreational athletes may be hindered by systemic pathologies that appear as sport related injury, however on closer inspection they are later diagnosed with Rheumatoid Arthritis (RA). The aims of this study endeavour to investigate the effects of RA on recreational athletes in the Cypriot population, more specifically physical ability, mental perceptions, behavioural choices and the use of alternative therapeutic modalities of treatment. Methods: Six recreational athletes (3 males and 3 females, mean \pm SD $41.33 \pm 15.85$ years) diagnosed with RA were selected for this study. All participants were of Cypriot nationality and were involved in physical activity of $5+$ hours per week. Participants were required to undergo a Multi-Dimensional Health Assessment Questionnaire (MDHAQ) and a semi-structured reflective interview. Results: The data collected from both the interview and the MDHAQ are directly related to the participant's current state (present time evaluation) of disease. Participants in this study had a mean score of 3.04 resulting in a moderate severity rating on the MDHAQ. Seven prominent reoccurring themes were present amongst the six participants. Discussion: Themes indicate an overlap in patient phenomenon and perspective. The detailed insights may possibly aid the future development and research into the effects of RA on patient well-being, a more optimal treatment and care plan for therapy and support. Conclusion: Recreational athletes suffering from RA may be limited in daily physical activity and participation in recreational activity. The purpose of this study intended to draw themes between RA, physical activity limitations and recreational athlete perspectives.
\end{abstract}

Keywords: physical activity, sports medicine, therapeutic modalities of treatment, perspectives, Cyprus.

\begin{abstract}
Absztrakt - Bevezetés: A szabadidős sportolókat akadályozhatják a szisztémás kórképek, amelyek sporttal kapcsolatos sérülésként jelenhetnek meg, azonban alapos vizsgálat után késóbb kiderült, hogy reumatoid artritisz (RA) diagnózis van a háttérben. $E$ tanulmány célja annak vizsgálata, hogy az RA milyen hatással van a szabadidós sportolókra a ciprusi populációban, pontosabban a fizikai képességekre, a mentális érzékelésre, a viselkedési döntésekre és az alternatív terápiás módok alkalmazására. Módszerek: Hat rekreációs RA-ban szenvedő sportolót (3 férfit és 3 nót, átlag \pm SD 41,33 \pm 15,85 év) választottunk ki. Valamennyi résztvevő ciprusi állampolgárságú volt, és heti 5+ órás fizikai aktivitást végzett. A résztvevők többdimenziós egészségi állapotfelmérő kérdőíven (MDHAQ) és félig strukturált reflektív interjún vettek részt. Eredmények: Mind az interjúból, mind az MDHAQ-ból összegyújtött adatok közvetlenül kapcsolódnak a résztvevő jelenlegi állapotához (a jelen idő értékeléséhez). A vizsgálatban résztvevők átlagos pontszáma 3,04 volt, ami közepes súlyossági besorolást eredményezett az MDHAQ-n. Hét kiemelkedő, ismétlődő téma (kapcsolat) volt jelen a hat résztvevó között. Megbeszélés: A témák a betegjelenség és a perspektíva átfedését jelzik. A részletes meglátások elősegíthetik az RA jövőbeni fejlődését és kutatását a betegek jólétére vonatkozóan, egy optimálisabb terápiás és támogatási kezelési és gondozási tervet. Következtetés: RA-ban szenvedó szabadidós sportolók számára korlátozott lehet a napi fizikai aktivitás és a rekreációs tevékenységekben való részvétel. A tanulmányunk célja az RA, a fizikai aktivitás korlátai és a szabadidós sportolók perspektívái közötti kapcsolatok megvilágítása volt.
\end{abstract}

Kulcsszavak: testmozgás, sportorvoslás, terápiás kezelési módok, perspektívák, Ciprus. 


\section{Introduction}

Recreational athletes partake in physical activity for both health and fitness benefits or simply for the pleasure of competition and enjoyment (Araujo \& Scharhag, 2016; Flodström et al., 2016). A large number of recreational athletes experience specific activity related injuries, which limit their ability to perform (Jennings et al., 2008). However for some recreational athletes there are systemic pathologies that at first appear as sports related injury but later with correct testing and evaluation can be directly linked to rheumatic related diseases (Hart 1994; Jari \& Noble, 2001; Jennings et al., 2008; Ravelli, 2007; Swigart \& Fishman, 2017). Furthermore, rheumatic disease can be linked to lower quality of life and general physical limitations in performing daily tasks (Jennings et al., 2008; Pollard et al., 2005; Salaffi et al., 2009).

The aim of the following study is to investigate through qualitative means the effects of rheumatoid arthritis (RA) on recreational athletes within the Cypriot population. More specifically to what extent RA affects recreational athlete's physical ability, mental perceptions, behavioural choices and the use of alternative therapeutic modalities of treatment. Sociological factors such as satisfaction, well-being, health, economic, medical, physical awareness, and education, perceptions will also be investigated in order to generate a holistic understanding of RA within recreational athletes. The attempt to look at patients as individuals in relation to their disease and experiences may result in new perspectives, leading to more in depth understanding of the non-theoretical ways RA limits patients (Clinch et al., 2001; Pincus et al., 2005).

This study also attempt to take into account the methods of treatment used in the past, present and the possibility of alternative interventions of treatment. The aim of this study is to collect perspective-based data from recreational athletes suffering from RA, with the intention of upgrading the knowledge and further develop the treatment and patient care of rheumatic disease in the sporting community of Cyprus.

\section{Recreational Athletes}

The term "recreational athlete" is at first read, inherently clear to understand, yet specifically defining the term is theoretical and speculative (Araujo \& Scharhag, 2016). This ambiguity has led to a hazy definition of the term, allowing for debate and individual interpretation (Araujo \& Scharhag, 2016). The word athlete has roots in the Greek word "Athlos" meaning to achieve (or achievement), therefore supposing performance or competition (Araujo \& Scharhag, 2016).

When comparing the general population to athletes it is commonly assumed that athletes are at the peak/optimal level of their physical fitness and health (Barry et al., 2014; De Brito et al., 2014; Feldman et al., 2015), but in several cases this may not be an accurate assumption (Chugh \& Weiss, 2015; Risgaard et al., 2014).

It is therefore perhaps more accurate to categorize athletes as having the primary desire of achievement and performance over health, well-being, or pleasure (Arem et al., 2015; Blair \& Haskell, 2006). In contrast the term recreational athlete may suppose then that achievement/competition and performance are important however not (primary or critical) to the detriment of health, well-being or pleasure (Araujo \& Scharhag, 2016).

Although it can be agreed that as no valid standardized definition exists, the topic of term-definition is beyond the scope of this paper (Maron et al., 2001, 2004, 2016; Pelliccia et al., 2008).

\section{Qualitative Vs Quantitative}

The concern of patient-specific perspectives is critical in understanding treatment, treatment effect, patient behaviour, perceptions and feelings towards themselves and their disease (Clinch et al., 2001). Assessment of feasibility, discrimination, and truth are elemental to determining the impact of treatment, care and patient behaviour (Clinch et al., 2001; Craig, 2011).

Although quantitative laboratory findings result in accurate and objective physiological outcomes, they lack the ability to ask the simple yet essential question "how do you feel?" (Cameron, 2001; Craig, 2002; Dunn et al., 2010; Zaki et al., 2012). The term interoception refers to the human perception of feeling, collectively the sense of what you feel within your body's physiological function determine your well-being (Cameron, 2001; Craig, 2002; Dunn et al., 2010; Zaki et al., 2012). Unfortunately, quantitative laboratory tests cannot divulge feeling, and for this reason qualitative research is absolutely integral to improving care and treatment (Cameron, 2001; Craig, 2002; Pincus et al., 2009). 


\section{Rheumatoid Arthritis}

Arthritis is a term most commonly associated with the elderly and the general pain and discomfort of the joints (Bernard, 2011; Lawrence et al., 2008). However, orthopaedists who assess recreational athletic patients with injury may find underlying rheumatic disease that contributes to the problem and symptoms (Jennings et al., 2008). The most common degenerative form, osteoarthritis, can be seen in most people, as they grow old (Grime et al., 2010). Osteoarthritis physiologically can be defined as the gradual breakdown of the protective cartilage at the end of bones (Patel \& Strauss, 2015). This disease is categorized as irreversible and can only be maintained with pain management and healthy lifestyle choices (Bernard 2011; Patel \& Strauss, 2015). RA is less common and is be the primary focus of this study due to the debilitating effects of this disease on physical activity (irrelevant of age) and the harsh modes of treatment (Jennings et al., 2008).

There are over 100 types of rheumatic diseases and all can be characterized with inflammation that affects tendons, ligaments, muscles, bones and joints (Bernard 2011; Kahn, 2013). In some rare cases rheumatic disease damage internal organs however this is far out of the scope of this study (Merrill et al., 2010). Orthopaedists usually first encounter patients with high levels of pain, swelling, joint pain, skin rash, and limited range of motion. After pathological testing, and radiographic findings the outcome may positively indicate some form of rheumatic disease (Jennings et al., 2008).

RA can be explained as an autoimmune disorder where the body's immune system attacks its own tissues; the swelling of joints occurs when the lining of joints becomes sensitive and inflamed creating pain and eventual erosion of the bone and joint (Kahn, 2009, 2013). RA has been proven to limit physical activity due to the intense pain experienced by patients (Bernard, 2011; Patel \& Strauss, 2015). RA often affects smaller joints of the feet and hands leading to deformity as joint surfaces become eroded (Kahn, 2013). Larger joints such as the shoulders, neck, knees, hips and ankles are also painfully inflamed by RA (Kahn, 2013). RA patients typically experience episodes or "flare ups", a period characterized by extreme inflammation and pain in a specific joint or area (Hewlett et al., 2011). In some cases, these episodes may affect both sides of the body simultaneously or just a single joint (Bernard, 2011; Hewlett et al., 2011).

More specific testing for RA may be required in order to make a conclusive diagnosis. Rheumatologists would then use the collected data to investigate further diagnosis and treatment options based on the specific type of rheumatic disease presented (Bernard, 2011, Kahn, 2009, 2013).

Although laboratory testing is essential and, in many cases, beneficial to the diagnosis of RA, there are variables that may affect the outcomes of the above tests, leading to an inaccurate result (Aletaha et al., 2010; Luime et al., 2010). For this reason, the combination of testing procedures are necessary to create overlapping or triangulated data in order to generate the most accurate diagnosis and eventual treatment (Nishimura et al., 2007). Additional testing such as x-rays, Magnetic Resonance Imaging (MRI's) and angiograms may be utilized to create more conclusive outcomes and treatment decisions (Nishimura et al., 2007). All of the above tests paired with the medical practitioners' evaluation typically results in the most accurate diagnosis and treatment care.

\section{Treatment of Rheumatoid Arthritis}

The most common form of treatment for RA is the use of pharmacological medication; a commonly used medication is Methotrexate a chemical compound administered weekly, relative to body weight (Micha et al., 2011). Methotrexate has been used for over 20 years and is considered the gold standard of RA treatment as it has shown to be significantly more effective that placebo in testing (Giannini et al., 1992). Methotrexate is classified as antimetabolite immune suppressing drug used to also treat cancer (Micha et al., 2011).

Although Methotrexate has been proven as effective the harsh side effects are far from desirable and should give rise to concern and caution when administering the drug (Hashkes et al., 1997; Micha et al., 2011). Adverse severe side effects common to Methotrexate include but are not limited to: azotemia, stomach or intestinal bleeding, blood platelet decrease, intestinal perforations, infection, inflammation of the gums and mouth, inflammation of stomach lining and intestinal tract, sepsis, stomach ulcer, and skin sensitivity to the sun (Curtis et al., 2016; Micha et al., 2011). 
No studies (to the author's knowledge based on multiple Google Scholar searches with the terms "Rheumatoid arthritis, Methotrexate and Cyprus or Cypriot) have been conducted to investigate patient's' tolerance of Methotrexate, and possible alternative modes of treatment in the Cypriot population. In recent years alternative drugs and modalities have been developed for the purpose of treating RA (Kahn, 2009, 2013). Ranging from variant chemical compounds, pharmacotherapy, intra-articular glucocorticoid injections and most recently biologics (Anti-TNFa therapy) (Gorter et al., 2010; Kahn, 2009, 2013). These alternative treatments may be a suitable possible replacement for Methotrexate; however, current research is limited and ongoing, and the current cost and accessibility is relatively high in comparison to Methotrexate (Curtis et al., 2016; Kahn, 2013; Lundkvist et al., 2008; Micha et al., 2011).

Irrelevant as to which method of treatment is selected, it is critical for medical practitioners to maintain regular treatment evaluation (Grigor et al., 2004). As mentioned above several prescribed medications may have potentially life-threatening side effects (Curtis et al., 2016; Kahn, 2013). It is imperative that the laboratory tests are used collectively or individually in order to evaluate the treatment and disease development of the patient (Grigor et al., 2004). It is essential that medical practitioners use the correct methods in order to gain better understanding of the treatment effects on the patient, be it negative or positive (Grigor et al., 2004; Singh et al., 2012).

\section{Quality of Life}

Although treatment has greatly improved the physical comfort of patients, little has been investigated to discover the patient's perceptions in regards to quality of life, physical ability, mental perceptions, sociological factors, behavioural choices and the use of alternative modalities of treatment, with in the Cypriot population (Lundkvist et al., 2008).

Perceptions of patient's interoception and opinions have been neglected failing to take into account patient reported outcomes and evaluations (Craig, 2011; Pincus et al., 2005). Although qualitative in nature, interoceptive perceptions and patient reported outcomes have shown to be beneficial in highlighting areas of key importance to the treatment care of patients with RA (Cohen et al., 2004; Craig, 2011; Pincus et al., 2005; Strand et al., 2004).

Studies have been conducted in the attempt of understanding the difference between patients with and without arthritis, different forms of treatment and in some cases different effects, however these studies have not been linked to current treatment plans or the evaluation of recreational athletes living with RA (Hutchinson et al., 2001; Smolen et al., 2006; Wolfe \& Michaud, 2004; Zautra et al., 2008). Moreover, these types of studies mentioned above have not been applied to the Cypriot population, highlighting a gap within the field of research.

A study conducted in The Netherlands in 2016 compared the physical activity of children (mean \pm DS age $10 \pm 1.4$ years) with juvenile idiopathic arthritis (JIA) and children without. Children with JIA had significantly lower physical activity levels than healthy children (Bos et al., 2016). Lower physical activity has been strongly linked to earlier mortality rates and generally lower quality of life (Bos et al., 2016). Physical activity has not been shown to exacerbate RA and is a fundamental characteristic in defining a recreational athlete as per the above criteria (Araujo \& Scharhag, 2016; Bos et al., 2016; Takken et al., 2008).

A study in Sweden was conducted in 2005, whereby researchers endeavoured to compare physical activity performance of non-athletes with RA. Each participant was required to undergo five fitness related physical tests. Thereafter, each participant was required to fill in a Health Assessment Questionnaire (HAQ). Findings for this study concluded with statically significantly lower performance results in patients with RA than that of the healthy population. Results may indicate that RA does in fact limit or hinder both physical performance and quality of life in patients (Eurenius \& Stenstrom, 2005). Similar studies reflect the same findings of decreased performance in patients diagnosed with RA (CDC 1997; Ekdabl \& Broman, 1992; Eurenius \& Stenstrom, 2005; Hootman et al., 2003).

Unfortunately to the determent of RA patients, quality of life, well-being, and the general perceptions of their disease and treatments are not well documented in the literature, with only minimal focus being placed on better understanding 
patient perspectives and behaviours. Regrettably this shortcoming in the literature is the same for the Cypriot population. Although Cypriot athletes may physically be no different from other athletes having undergone similar studies, the concept of "how do you feel" is largely based on personal experience, perception and is greatly influenced by external environmental factors unique to the Cypriot population, as Cypriot athletes have not been studied or observed for differences or similarities (Cameron, 2001; Craig, 2002; Dunn et al., 2010; Zaki et al., 2012).

\section{Research Objectives}

To the authors' knowledge no published studies have been conducted on the perspectives of Cypriot recreational athletes with regards to living with RA. No studies have been found that cover Cypriot patients' perception of alternative modalities of therapy to compare with their current treatment plan. Finally, no Multi-Dimensional Health Assessment Questionnaires (MDHAQ) has been used in qualitative based research within Cyprus. All of the above based on multiple Google Scholar searches with the terms "Rheumatoid arthritis and Cyprus, Cypriot, perspectives, MDHAQ or physical activity".

This situation motivated the authors to investigate the following research questions:

1. What are the effects of RA on recreational athletes within the Cypriot Population?

2. What are the patient perspectives of RA as per the above-mentioned areas of focus?

\section{Methods}

The study has endeavoured to better understand the perspective-based experiences of the Cypriot patients. For this reason, it was proposed that an Interpretive Phenomenological Analysis (IPA) design would be adhered to as it utilizes interviews and questionnaires as the bases for understanding the motivation/perspectives of recreational athlete's actions (Bolderston, 2012; Creswell, 2013). An IPA attempts to describe and conclude meaning from the collection of lived experiences of humans who have been involved in specific situations or events, and how the participants have been affected (Bolderston, 2012; Donalek, 2004). As per the guidelines of
IPA studies, between 5-25 participants should be included and interviews be conducted in order to draw any reoccurring themes, and conclusions from the data collected (Bolderston, 2012; Creswell, 2013).

\section{Ethical Guidelines}

The study was approved by the Cyprus $\mathrm{Na}$ tional Bioethics Committee in association with the ethical board of the University of Central Lancashire (UCLan Cyprus). All participants had given written consent prior to any participation in this study according to ethical standards (Harriss \& Atkinson, 2015).

\section{Participants}

Six recreational athletes with an age range of 25 to 58 years old ( 3 males and 3 females, mean $\pm S D$ age $41.33 \pm 15.85$ years) diagnosed with RA were selected for this study. All participants were of Cypriot nationality, primarily living and working/studying in Cyprus.

Local Cypriot rheumatologists as well as the Cypriot Organization of Rheumatism were contacted telephonically and via email to fully explain the purpose and aims of the study. Once the selected rheumatologists were fully informed regarding the methods and purpose of the study, the specialists were requested to ask their patients if they (the patient) would be interested in participating in the study. Selected rheumatologists had to give their consent to the study; patients meeting the specific criteria were directly contacted requesting and confirming their participation in this study. Furthermore, a public proposal email was sent to all university students and faculty of UCLan Cyprus in order to improve participant recruitment.

Participants were included in this study if they met the criteria included in Table 1.

Participants were excluded based on a point system of applicable exclusions (Table 2). In the event that a participant scored lower than 3 and met all of the inclusion criteria they were included within the study.

Once relevant participants had been recruited, personal data were collected using a modified information form. All personal data collected were kept private and confidential coded to ensure full anonymity. 


\section{Interviews}

Long semi-structured reflective interviews were conducted. Twelve open ended questions were designed and created specifically with the intention of extracting the most amount of relevant data from each participant, Table 3 reflects the main topics of investigation. Follow up questions were not included as each follow-up question differed based on individual participant response. A semistructured interviewing style was utilized in order to allow a free flow of conversational information (Bolderston, 2012). As per guidelines of IPA the focus of the investigation is to examine and describe the phenomenon that participants are experiencing (Bolderston, 2012).

Table 1: Inclusion Criteria

\section{Eligible participants will be required to meet all four criteria}

- Participant has been diagnosed with Rheumatoid arthritis.

- Participant is a recreational athlete who is involved in any physical activity of 5 hours or more per week. Physical activity may include but not limited to (resistance training, athletic training, walking, jogging, running, and gardening. Any forms of manual labour, any typical sports i.e.: tennis, swimming, football, rugby, volleyball, basketball, pilates, yoga, etc).

- Participant is aged between 18-60 years.

- Participant is a Cypriot national.

Table 2: Exclusion Criteria

\begin{tabular}{|l|}
\hline $\begin{array}{l}\text { All participants scoring higher than } \mathbf{3} \text { were considered } \\
\text { unsuitable (No=0, Yes=1) }\end{array}$ \\
\hline - Has alternative variation of arthritis (Osteoarthritis, psoriatic \\
arthritis, fibromyalgia, gout, etc) \\
- Has undergone surgery on related arthritic joins \\
- Currently does not take any treatment for pain \\
- Does not have a formal arthritis evaluation \\
- Participant is an anthlete as defined by table 1
\end{tabular}

\section{Data Collection}

Each participant was personally contacted to arrange a specific date, time, and location in order to conduct a face-to-face, one-on-one interview. Each participant was required to fill and sign their welcome pack prior to any interview. Each participant was additionally required to undergo a Multi
Dimensional Health Assessment Questionnaire (MDHAQ). The use of multiple sources of data collection, i) welcome pack, ii) semi structured interview and, iii) MDHAQ, describe the action of triangulation, improving validity and reliability of outcomes to follow (Bolderston, 2012). 
Table 3: Interview Topics

\begin{tabular}{|l|}
\hline Summary of open-ended question topics \\
\hline 1. Effects of RA: \\
- Sporting activity \\
- Daily life \\
- General limitations \\
2. Management of RA: \\
- Treatments \\
- Side effects \\
- Alternative modes of treatment \\
- Perceptions of RA: \\
- Psychological \\
- Emotional \\
- Economic factors \\
- Disease support structures
\end{tabular}

All interviews were digitally audio recorded using a Samsung S9+ Voice Recorder (version 21.0.20.25, Samsung Electronics CO. LTD). Interviews were conducted at the most convenient location and time for the participant. Prior consent was given to use the voice recorder before all interviews. To ensure quality control and professionalism emails were sent to the participant, doctor, and university regarding interview time, date and location for validation and ethical concerns.

After each interview was completed voice recordings were transcribed and analysed for reoccurring themes and trends. Transcription of interviews took place after each day's interviews and saved in digital format on a Microsoft Word document (Version 2007, Microsoft Office).

Each interview was carefully listened to and read over several times, and then an analysis was conducted to draw reoccurring themes from each interview. An open coding structure was employed for the initial use of the study, to highlight the perspectives of participants experiencing the phenomenon. Thereafter axial coding was used as a secondary level of analysis dependant on the interview outcomes (Bolderston, 2012).

\section{Multi-Dimensional Health Assessment Questionnaire (MDHAQ)}

The MDHAQ is a clinical tool designed and used by rheumatologists in the evaluation of patients diagnosed with RA (Pincus et al., 1999,
$2005,2005)$. The questionnaire is a two-page document designed to be answered easily and honestly by the patient (Pincus et al., 1999, 2005, 2005). The MDHAQ is designed in such a way that rheumatologists can read and score the questionnaire within 15-20 seconds respectively (Pincus et al., 2005). The MDHAQ is considered the gold standard questionnaire for all rheumatic disease evaluation (Pincus et al., 2005). The MDHAQ has been widely used with success in the assessment of RA, in both pre and post treatment evaluation (Maska et al., 2011).

The MDHAQ was selected for this study as a complimentary addition to the open-ended interviews; overlapping data have shown to improve reliability and validity through triangulation of sources (Bolderston, 2012). The MDHAQ has been shown to be as effective as current clinical measures, including radiographs and laboratory tests in the assessment of RA (Pincus et al., 1999, 2005, 2005). The use of the MDHAQ has been correlated significantly with data from laboratory tests and selective radiographs in the evaluation of functional disability, financial costs, work disability, premature mortality, joint replacement surgery and changes in perspective based clinical research (Pincus et al., 1999, 2005, 2005).

In order to gain legal access and licence to use the MDHAQ, a master licence agreement (MLA) had to be drafted and signed for the specific use in this study. Application for permission of use 
was granted following a detailed proposal submission to RWS Life Sciences. Thereafter the MLA was drafted between RWS Life Sciences and the researcher of this study for the purposes detailed above, (RWS Life Sciences, 101 East River Drive, East Hartford, CT 06108, USA, Dr Theodore Pincus, $M D)$.

Each participant was given the MDHAQ to answer; the participants were instructed to try to answer every question, even if they did not believe it was applicable to them. The participants were instructed to try and complete as much of the questionnaire on their own but should ask for help if they required it. Each participant was clearly told that there were no wrong or right answers and that they should answer the questions exactly as they felt (Pincus et al., 2005).

\section{Reflexivity}

Finally, the limitation of bias was addressed. Reflexivity was conducted in order to self-evaluate personal beliefs and preconceptions regarding the specific area of study. Through a process of bracketing the researchers set aside all personal ideas, theories, personal experiences, bias and preconceived notions in order to remain objective towards the study and ensure that the integrity, validity and reliability of the study is not compromised (Bolderston, 2012; Donalek, 2004).

After all the interviews had been completed and transcribed, all MDHAQ's had been filled in, and all welcome packs had been collected, the data analysis was reflected upon. The analysis attempted to draw conclusions between the above-mentioned sources of data. Utilizing the above coding strategies, conclusions and evaluations were developed and refined.

\section{Results}

The data collected from both the interview and the MDHAQ are directly related to the participant's current state (present time evaluation) of disease, unless specified otherwise. Descriptive statistics regarding the participants can be seen in Table 4.

Table 4: Descriptive Participant Characteristics $n=6$, Mean \pm SD

\begin{tabular}{|c|cc|}
\hline Measure & Mean & SD \\
\hline Age & 41.33 & 15.85 \\
\hline MDHAQ (MS) & 3.04 & 1.92 \\
\hline Physical Activity hours per week & 8.67 & 2.50 \\
\hline $\begin{array}{c}\text { Severe Pain (VAS 0=No Pain 10=Max Pain ) } \\
\text { Well-Being (VAS 0=Very Well 10=Very } \\
\text { poor) }\end{array}$ & 4.75 & 2.32 \\
\hline
\end{tabular}

MDHAQ scores are reflected in degrees of severity on a scale of $0-10$; Near Remission (NR) = 0-1.0, Low Severity $(\mathrm{LS})=1.3-2.0$, Moder ate Severity $(\mathrm{MS})=2.3-4.0$, and High Severity $(H S)=4.3-10$, (Pincus et al., 2007). Participants in this study had a mean score of 3.04 resulting in a moderate severity rating (Pincus et al., 2007). VAS scores are inclusive of the MDHAQ; however, the scores have been singled out as comparative measure of data. VAS scales attempt to visually evaluate participant's feeling, beliefs, and attitudes towards symptoms or pain. The decision of this extraction was motivated by the intention of strengthening the findings to follow.

After the use of an emergence strategy involving a thematic analysis, collective and individual themes were categorized. Through open and axial coding individual and collective reoccurring themes were collated and sorted as per IPA guidelines, Table 5 and Table 6, (Bolderston, 2012; Creswell, 2013; Donalek, 2004). 
Table 5: Individual Themes

\begin{tabular}{|c|c|}
\hline \multicolumn{2}{|c|}{ Individual Participant Interview Characteristics } \\
\hline Individual Theme Categories & Direct Quotes from Participant Interviews* \\
\hline $\begin{array}{l}\text { a. Physical activity: Avoidance of pain/injury/ } \\
\text { high risk activity, decreased physical performance, } \\
\text { mentally and physically impaired, longer recovery } \\
\text { times, behavioural adjustment/compensation/ } \\
\text { avoidance of particular high risk or pain incurring } \\
\text { activities, has the desire to be more physically active, } \\
\text { use of specific physical activity to improve physical } \\
\text { and psychological symptoms of RA. }\end{array}$ & $\begin{array}{l}\text { a. - "I'm minimizing the risk with individualized } \\
\text { programming" } \\
\text { a. - "I needed to figure out better approaches to avoid } \\
\text { injury and pain" } \\
\text { a. - "Exercising makes me feel alive again, I only wish I } \\
\text { could do more" } \\
\text { a. - "I thought swimming therapy was for old people, but } \\
\text { it really helps me stay active without pain..." }\end{array}$ \\
\hline $\begin{array}{l}\text { b. Life: General daily activity avoidance and } \\
\text { limitation due to pain or risk of injury, daily } \\
\text { activities influenced and manipulated by symptoms } \\
\text { of RA, feelings of frustration due to impaired ability, } \\
\text { mental and physical stress avoidance to limit RA } \\
\text { flare ups, avoidance of social interactions, reclusive } \\
\text { behaviour, total holistic control is required to } \\
\text { maintain symptoms. }\end{array}$ & $\begin{array}{l}\text { b. - "I had to work a lot on well-being, and well-being } \\
\text { means for me, trying to minimize my stress, because stress } \\
\text { on your organism is not only stress on the psychological, } \\
\text { it is also physical." } \\
\text { b. - "It's a daily battle it's the only thing that makes me } \\
\text { seriously depressed, it restricts me from doing so many } \\
\text { things that I want to do." } \\
\text { b. - "I eat, sleep, train and live with my RA, I plan my } \\
\text { life to avoid negative side effects" }\end{array}$ \\
\hline $\begin{array}{l}\text { c. Medication: Avoidance of medications with } \\
\text { harsh negative side effects, high value on holistic } \\
\text { treatment/management, willingness to use multiple } \\
\text { alternative treatment options, general well-being } \\
\text { motivates types of medication usage options, specific } \\
\text { exercise used commonly as a daily treatment option. }\end{array}$ & $\begin{array}{l}\text { c. - "I did not want to go back to taking the cortisone" } \\
\text { c. - "I try to use the alternative" } \\
\text { c. - "Meditation, REIKI, self-management, massage, } \\
\text { chiropractic treatment, drugs, I've tried them all..." } \\
\text { c. - "In the past the medications gave me terrible stomach } \\
\text { problems, I still feel like my stomach is weak." } \\
\text { c. - "physical activity, eating well, and resting help a lot." }\end{array}$ \\
\hline $\begin{array}{l}\text { d. Perspectives: People do not realise/understand/ } \\
\text { acknowledge the pain and symptoms associated with } \\
\text { RA, lack of empathy from others, lack of education } \\
\text { on RA, lack of support for RA patients, RA patients } \\
\text { often labelled as lazy, weak, or unmotivated. }\end{array}$ & $\begin{array}{l}\text { d. - "I don't think they realize how it affects you until } \\
\text { you explain to them." } \\
\text { d. - "They think that you're actually just a bit stiff, they } \\
\text { underplay what you have they can't really appreciate the } \\
\text { pain." } \\
\text { d. - "Most people I speak to think RA is for old people } \\
\text { only, they have no idea about the pathologies behind } \\
\text { RA." }\end{array}$ \\
\hline $\begin{array}{l}\text { e. Emotional/psychological: Feelings of inadequacy, } \\
\text { frustration, anxiety for the future symptoms, } \\
\text { isolation, loneliness, depression, emotional tiredness, } \\
\text { shame, embarrassment, animosity towards RA, } \\
\text { apprehension towards activity, regret for time lost, } \\
\text { longing to feel healthy, the importance of mental } \\
\text { toughness and focus. }\end{array}$ & $\begin{array}{l}\text { e. - "So when I stand between my fellow athletes in the } \\
\text { gym, I have a point to prove." } \\
\text { e. - "If I was not mentally strong in my mind, I would } \\
\text { never be able to do it, I would have given up a long time } \\
\text { ago." } \\
\text { e. - "Some days I just want to sleep, the whole day } \\
\text { without waking up, it feels easier..." } \\
\text { e. - "I wonder how I will be when I'm } 80 \text { years old; I } \\
\text { worry about falling or getting injured. What will I do } \\
\text { then?" } \\
\text { e. - "I want to perform, I want to compete, but I cannot, } \\
\text { it makes me mad that maybe I could be great, but I } \\
\text { cannot..." }\end{array}$ \\
\hline
\end{tabular}

* Only selective quotes pertaining to the themes have been included, due to logistical limitations. 


\section{Discussion}

The above findings indicate that seven prominent reoccurring themes were present amongst the six participants, Table 6 . The findings further indicate that the use of a semi-structured reflective interview in combination with a MDHAQ allowed to triangulate and reveal insights into the effects of RA on recreational athletes, specifically within the Cypriot population. As mentioned, the aim of this study was to investigate recreational athletes of the Cypriot population living with RA. The highlighted intention was to focus on individual perspectives and derive meaning from participant responses.

The following predominant reoccurring themes were identified (Table 6).

Table 6: Collective Reoccurring Themes*

1. Physical activity and daily behaviours are influenced, manipulated and limited by RA

2. RA directly reduces social interaction and pleasure

3. Physical activity is beneficial to RA pain reduction

4. Patients avoid and terminate the use of medications due to harsh negative side effects

5. Holistic approaches are beneficial to RA management

6. People lack understanding and empathy towards RA

7. Patients had strong feelings of depression, anxiety, and frustration, due to RA and the limiting effects on physical activity and daily life

* Listed in order of first observed or established, not listed by importance or frequency.

The seven themes will be discussed in detail to evaluate and reveal the human experience of RA. The participants provided descriptions and details of their perspective of living with RA as recreational athletes.

Theme 1: Physical activity and daily behaviours are influenced, manipulated and limited by $R A$.

This theme was derived by responses of most of the participants, as the participants are all physically active people it would appear that they all have to some degree a level of intrinsic motivation to stay physically active. This level of intrinsic motivation is clearly in direct conflict with the limiting nature of pain and RA.

Many of the participants expressed their feelings of being "held back" by their RA, both by pain and the fear of injury. The consistent need to avoid pain and injury directly manipulates decision making in regard to what activities may illicit more or less pain. A repeating trend amongst participants was the need for physical compensation. Participants had the need to modify training behaviour, exercise, or movements in order to remove pain or the possibility of injury. Multiple participants have made purposeful training routines specifically in the attempts to reduce pain and strengthen against the chance of injury, in line with current literature (Tierney et al., 2013).
This continual behavioural adaption left participants feeling limited to certain activities, and ultimately frustrated with the physical inability to perform desired tasks. Furthermore, this frustration carried over into daily tasks such as, opening a jar, using a screwdriver or climbing stairs. Similar findings were established regarding pain limitations and behavioural changes within the literature (Aletaha et al., 2010; Tierney et al., 2013; Wiech \& Tracey, 2009).

Theme 2: $R A$ directly reduces social interaction and pleasure.

Following on from the above theme of limitation, it was identified that RA also has a limiting effect on social behaviour as much as physical behaviour modifications. Participants repeatedly expressed their disdain for social interaction during flare ups. Pain had a direct influence over their feeling to leave the house and interact with other people on a pleasurable or social level. One participant expressed her greatest desire during a flare up was to simply sleep for as long as possible until the pain had left.

It appears that this feeling of apathy towards people and social activity carried over to loved ones and family members too. One participant expressed that he would rather tell his wife that he was just tired as to allow him time alone to rest, 
rather than being given attention about his RA. It must be noted that these feelings of detachment and disaffection predominantly occurred during times of flare up or increased stress and pain.

The above behaviour may be explained as a simple coping mechanism as suggested by research, (Osterweis et al., 1987). It has been suggested that atypical coping behaviour may be a response to the feeling of being threatened or vulnerability (Van Damme et al., 2008). Although this type of coping mechanism can be reclusive and possibly mentally unhealthy research has shown that the need to be alone may also provide a time of energy reduction and aid in the resting process (Wachholtz et al., 2007).

Theme 3: Physical activity is beneficial to RA pain reduction.

All participants explicitly expressed the positive feeling exercise/ physical activity produced for them. Furthermore, all participants noted the pain reduction physical activity provided them. One participant stated that his training makes him feel "normal and healthy again" for a few hours, and once he had terminated training a few hours later he could feel the RA pain returning.

The importance of physical activity to the participants extended beyond positive feelings and has also been applied as a form of therapy for their pain. Several participants have selected training routines specifically designed to reduce RA pain; this is used in conjunction with their normal training routines.

These findings are strongly supported by published research with regards to the positive effects of physical activity, on physiological, mental and emotional health (Fredrickson, 2003; Janssen \& LeBlanc, 2010; Reiner et al., 2013; Warburton et al., 2006). More specifically the above experiences directly concur with similar research investigating the positive effects of physical activity and RA (Cooney et al., 2011; Knittle et al., 2011; Philpott et al., 2010).

Theme 4: The avoidance and termination of medications due to harsh negative side effects.

Of the six participants all had been prescribed glucocorticoid co-therapy (cortisone, corticosteroids) to treat flare ups or maintain RA.

Further all participants had experienced negative side effects (gut problems, immunodeficiency, impaired glucose tolerance, muscular problems, strength decrease, weakness, weight gain/loss, and skin sensitivity) of glucocorticoid co-therapy and have consequently terminated the use of this form of treatment. Although cortisone has been shown to be an effective treatment for acute RA flare ups, it has also been shown to result in many unwanted side effects as experienced by the participants (Benedek, 2011; Dixon et al., 2018; Hoes et al., 2010; Van der Goes et al., 2014).

Initially it had been supposed that Methotrexate would be the predominantly negative medication as per literary findings (Giannini et al., 1992; Hashkes et al., 1997; Micha et al., 2011); however, it appears that within the context of this study, Methotrexate had only been used by two participants. In both these cases negative side effects had been experienced as per the literature (Curtis et al., 2016; Micha et al., 2011), and consequently terminated for alternative therapies.

Participants had hostile feelings towards many pharmacological treatment options primarily motivated by harsh negative side effects. Participants had experienced unsatisfactory results with many of the medications they had used; specifically, the negative side effects outweighed the therapeutic effect.

When asked about their thoughts on trying new medications, many participants expressed caution due to past experiences, and would only opt for medications with lower expected side effects. Although all participants exercised caution, they did express a deep willingness to try new alternative therapies in the hope of finding a viable solution.

Theme 5: Holistic approaches are beneficial to $R A$ management.

Following the topic above it had been predominantly identified that participants have the need to control multiple aspects of their life, which lead to the most effective management of RA. As opposed to using one form of treatment, many participants had discovered through experience that controlling and taking care of different variables resulted in the best pain relief, thus leading to a better quality of life, and feeling of well-being.

Several participants made a clear point that complete control was vital to them feeling better. A combination of eating well, resting sufficiently, avoiding injury and pain, exercising regularly, and ensuring that stress levels are managed; they were able to find a holistic balance to their RA. 
Participants noted that by controlling the above factors they were able to maintain a level of acceptable pain, and limit the need and use of pharmacological solutions.

Participants further noted that a clear distinction could be made when their stress levels began to rise, so did their RA symptoms. The above theme concurs with similar findings in literature regarding holistic well-being management and health (Metin \& Ozdemir, 2016; Taibi \& Bourguignon, 2003; Zautra et al., 2008).

Theme 6: People lack understanding and empathy towards $R A$.

Consistently when each participant was asked about the external perceptions of their disease by others a strong and clear statement was held by all, "people do not understand what RA pain is like". Variations of this same notion protruded that non RA sufferers could not, or did not understand RA or the pain associated with RA. Participants repeated that they had the continual need to explain their disease to people before they (non RA sufferers) could begin to respect the participant's limitations. Participants further expressed the need to improve general public education regarding rheumatism and rheumatic disease to improve empathy towards RA sufferers.

Participants expressed that non-RA sufferers assumed that participants were either, i) over exaggerating the pain, or ii) avoiding certain tasks/activities due to lack of motivation. These reactions by non-RA sufferers may be an influencing factor to the reclusive behaviour of participants observed above in theme 2 .

Research has highlighted that the poor quality of patient empathy in RA patients, has the need for advancement and development, in order to improve patient treatment and care (Kvrgic et al., 2017). Discordance between patient communication and empathy (by, medical practitioners) was strongly related to well-being and treatment care (Kvrgic et al., 2017). A systemic review in 2018 highlighted the critical importance of patient empathy in RA and treatment care as vital to wellbeing and RA management (Minnock et al., 2018).

Theme 7: Strong feelings of depression, anxiety, and frustration, due to $R A$ and the limiting effects on physical activity and daily life.

As per literary findings, the emotional and physiological effects of RA appear to overlap within the
Cypriot community and among the participants of this study (Flurey et al., 2016; Matcham et al., 2016). The development of depression, anxiety and frustration was identified which concurs with current studies of pain and emotional outcomes (Englbrecht et al., 2016; Fiest et al., 2017; Flurey et al., 2016; Gossec et al., 2016; Matcham et al., 2015).

Participants felt a sense of desperation which conceptually added to the larger, more complex topic of depression. The feeling of desperation stemmed from possible future limitations, the "what if" factor seemed to play an integral role in this emotion. Participants repeatedly stated that "they are ok for now", indicating that old age or possible flare-ups generate fear or disruption in positive feelings. These feelings of depression were strongly overlapped with feelings of anxiety, constant worry about the negative development of their disease.

Finally, it was identified that frustration continually disrupted participants' sense of well-being. The frustration appears to stem from the inability to do certain desired tasks, due to pain or the fear of possible injury. Multiple participants expressed that they had the continual desire to do more physical activity but simply could not due to RA.

\section{Limitations of the study}

Although the above findings have revealed several intriguing meanings and identifications regarding the effects of RA on recreational athletes, it must be noted that all of the above findings are heavily reliant on the subjective human experience of each participant. The subjective nature of these findings thus limits generalisation, applicability and population representation. The addition of more quantitative data such as physical examinations or laboratory testing in conjunction to the qualitative data would allow for more objective and measurable outcomes for generalisation.

Furthermore, the small sample size needs to be addressed, although according to IPA guidelines 5-25 participants are sufficient to draw conclusions, this does not imply accurate representation of the Cypriot population (Bolderston, 2012). Thus, future studies should include a larger sample size of both genders in order to rectify this limitation.

Language has been identified as a possible limitation due to communication deviations and 
possible limited translational errors. This may have led to i) limited responses and ii) possible inaccurate answers. Future studies need to recruit professional translational services in order to remove this chance for error and improve the accuracy of participant understanding and feedback.

\section{Conclusion}

The present study endeavoured to investigate and better understand the effects of RA on recreational athletes within the Cypriot population. The study focused on the effects and perspectives as initial research questions from the forefront. The data collected and analysed resulted in seven distinct themes, each of these themes benefited the further understanding of the research topic of recreational athletes living with RA.

The findings have yielded a deeper and more concise knowledge of the research questions and the topic of study. The outcomes of this study are both relevant and applicable to the Cypriot population and the sporting community living with RA.

Although the outcomes are subjective and qualitative in nature, they are able to provide perspective on a phenomenon that exits. The findings are applicable to recreational athletes with RA, patients with RA and medical practitioners specializing in RA. The detailed insights may possibly aid the future development and research into the effects of RA and patient's well-being for a more optimal treatment and care plan for therapy and support of patients and recreational athletes within Cyprus.

\section{References}

1. Aletaha, D., Neogi, T., Silman, A. J., Funovits, J., Felson, D. T., Bingham, C. O., Cohen, M. D. (2010). 2010 rheumatoid arthritis classification criteria: an American College of Rheumatology/European League Against Rheumatism collaborative initiative. Arthritis \& Rheumatology, 62(9), 2569-2581. https:// doi.org/10.1002/art.27584

2. Araújo, C. \& Scharhag, J. (2016). Athlete: a working definition for medical and health sciences research. Scandinavian Journal of Medicine \& Science in Sports, 26(1), 4-7. https://doi.org/10.1111/sms.12632

3. Arem, H., Moore, S. C., Patel, A., Hartge, P.,
De Gonzalez, A. B., Visvanathan, K., Adami, H. O. (2015). Leisure time physical activity and mortality: a detailed pooled analysis of the dose-response relationship. JAMA Internal Medicine, 175(6), 959-967. https://doi. org/10.1001/jamainternmed.2015.0533

4. Barry, V. W., Baruth, M., Beets, M. W., Durstine, J. L., Liu, J. \& Blair, S. N. (2014). Fitness vs. fatness on all-cause mortality: a meta-analysis. Progress in Cardiovascular Diseases, 56(4), 382-390. https://doi. org/10.1016/j.pcad.2013.09.002

5. Benedek, T. G. (2011). History of the development of corticosteroid therapy. Clin Exp Rheumatol, 29(5, 68), 5.

6. Bernard Jr., Thomas N. Hughston. (2011). Rheumatic Disease in Orthopaedic Patients. Health Alert Spring, 23(2), 1-3.

7. Blair, S. N. \& Haskell, W. L. (2006). Objectively measured physical activity and mortality in older adults. Jama, 296(2), 216218. https://doi.org/10.1001/jama.296.2.216

8. Bolderston, A. (2012). Conducting a research interview. Journal of Medical Imaging and Radiation Sciences, 43(1), 66-76. https://doi. org/10.1016/j.jmir.2011.12.002

9. Bos, G. J., Lelieveld, O. T., Armbrust, W., Sauer, P. J., Geertzen, J. H. \& Dijkstra, P. U. (2016). Physical activity in children with Juvenile Idiopathic Arthritis compared to controls. Pediatric Rheumatology, 14(1), 42. https://doi.org/10.1186/s12969-016-0102-8

10. Cameron, O. G. (2001). Visceral sensory neuroscience: interoception Oxford University Press.

11. Centers for Disease Control and Prevention, (CDC). (1997). Prevalence of leisure-time physical activity among persons with arthritis and other rheumatic conditions--United States, 1990-1991. MMWR.Morbidity and Mortality Weekly Report, 46(18), 389-393.

12. Chugh, S. S. \& Weiss, J. B. (2015). Sudden cardiac death in the older athlete. Journal of the American College of Cardiology, 65(5), 493-502. https://doi.org/10.1016/j.jacc.2014.10.064

13. Clinch, J., Tugwell, P., Wells, G. \& Shea, B. (2001). Individualized functional priority approach to the assessment of health related quality of life in rheumatology. The Journal of Rheumatology, 28(2), 445-451. 
14. Cohen, S. B., Strand, V., Aguilar, D., \& Ofman, J. J. (2004). Patient-versus physician-reported outcomes in rheumatoid arthritis patients treated with recombinant interleukin-1 receptor antagonist (anakinra) therapy. Rheumatology, 43(6), 704-711. https://doi. org/10.1093/rheumatology/keh152

15. Cooney, J. K., Law, R. J., Matschke, V., Lemmey, A. B., Moore, J. P., Ahmad, Y., Thom, J. M. (2011). Benefits of exercise in rheumatoid arthritis. Journal of Aging Research, 2011, 681640. 10.4061/2011/681640 https://doi.org/10.4061/2011/681640

16. Craig, A. D. (2011). Significance of the insula for the evolution of human awareness of feelings from the body. Annals of the New York Academy of Sciences, 1225, 72-82. 10.1111/j.1749-6632.2011.05990.x https:// doi.org/10.1111/j.1749-6632.2011.05990.x

17. Craig, A. D. (2002). How do you feel? Interoception: the sense of the physiological condition of the body. Nature Reviews Neuroscience, 3(8), 655. https://doi. org/10.1038/nrn894

18. Creswell, J. W. (2013). Research design: Qualitative, quantitative, and mixed methods approaches Sage publications.

19. Curtis, J. R., Xie, F., Mackey, D., Gerber, N., Bharat, A., Beukelman, T., Ginsberg, S. (2016). Patient's experience with subcutaneous and oral methotrexate for the treatment of rheumatoid arthritis. BMC Musculoskeletal Disorders, 17(1), 405. https:// doi.org/10.1186/s12891-016-1254-x

20. De Brito, Leonardo Barbosa Barreto, Ricardo, D. R., de Araújo, Denise Sardinha Mendes Soares, Ramos, P. S., Myers, J. \& de Araújo, Claudio Gil Soares. (2014). Ability to sit and rise from the floor as a predictor of allcause mortality. European Journal of Preventive Cardiology, 21(7), 892-898. https://doi. org/10.1177/2047487312471759

21. Dixon, W. G., Abrahamowicz, M., Ray, D. W., Bernatsky, S. \& Suissa, S. (2018). Re: Confounding by indication invalidates most observational studies on side effects of glucocorticoids.

22. Donalek, J. G. (2004). Phenomenology as a qualitative research method. Urologic Nursing, 24(6), 516.
23. Dunn, B. D., Galton, H. C., Morgan, R., Evans, D., Oliver, C., Meyer, M., Dalgleish, T. (2010). Listening to your heart: How interoception shapes emotion experience and intuitive decision making. Psychological Science, 21(12), 1835-1844. https://doi. org/10.1177/0956797610389191

24. Ekdahl, C., \& Broman, G. (1992). Muscle strength, endurance, and aerobic capacity in rheumatoid arthritis: a comparative study with healthy subjects. Annals of the Rheumatic Diseases, 51(1), 35-40. https://doi. org/10.1136/ard.51.1.35

25. Englbrecht, M., Alten, R., Aringer, M., Baerwald, C. G., Burkhardt, H., Eby, N., Henkemeier, U. (2016). No title. FRI0142 High Prevalence of Depression in Patients with Rheumatoid Arthritis-Data from the Large Cross-Sectional Vadera II Study, https://doi. org/10.1136/annrheumdis-2016-eular.3236

26. Eurenius, E. \& Stenström, C. H. (2005). Physical activity, physical fitness, and general health perception among individuals with rheumatoid arthritis. Arthritis Care \& Research, 53(1), 48-55. https://doi.org/10.1002/ art.20924

27. Feldman, D. I., Al-Mallah, M. H., Keteyian, S. J., Brawner, C. A., Feldman, T., Blumenthal, R. S. \& Blaha, M. J. (2015). No evidence of an upper threshold for mortality benefit at high levels of cardiorespiratory fitness. Journal of the American College of Cardiology, 65(6), 629-630. https://doi.org/10.1016/j. jacc.2014.11.030

28. Fiest, K. M., Hitchon, C. A., Bernstein, C. N., Peschken, C.A., Walker,J.R., Graff,L.A., CIHR Team „Defining the Burden and Managing the Effects of Psychiatric Comorbidity in Chronic Immunoinflammatory Disease". (2017). Systematic Review and Meta-analysis of Interventions for Depression and Anxiety in Persons with Rheumatoid Arthritis. Journal of Clinical Rheumatology: Practical Reports on Rheumatic \& Musculoskeletal Diseases, 23(8), 425-434. 10.1097/RHU.0000000$000000489 \quad$ https://doi.org/10.1097/ RHU.0000000000000489

29. Flodström, F., Heijne, A., Batt, M. E. \& Frohm, A. (2016). THE NINE TEST SCREENING BATTERY-NORMATIVE VALUES ON A 
GROUP OF RECREATIONAL ATHLETES. International Journal of Sports Physical Therapy, 11(6), 936.

30. Flurey, C. A., Hewlett, S., Rodham, K., White, A., Noddings, R. \& Kirwan, J. R. (2016). Identifying different typologies of experiences and coping strategies in men with rheumatoid arthritis: a Q-methodology study. BMJ Open, 6(10), e012051-012051. 10.1136/bmjopen-2016-012051 https://doi. org/10.1136/bmjopen-2016-012051

31. Fredrickson, B. L. (2003). The value of positive emotions: The emerging science of positive psychology is coming to understand why it's good to feel good. American Scientist, 91(4), 330-335. https://doi.org/10.1511/2003.4.330

32. Giannini, E. H., Brewer, E. J., Kuzmina, N., Shaikov, A., Maximov, A., Vorontsov, I., Zemel, L. S. (1992). Methotrexate in resistant juvenile rheumatoid arthritis: results of the USA-USSR double-blind, placebocontrolled trial. New England Journal of Medicine, 326(16), 1043-1049. https://doi. org/10.1056/NEJM199204163261602

33. Gorter, S. L., Bijlsma, J. W., Cutolo, M., Gomez-Reino, J., Kouloumas, M., Smolen, J. S. \& Landewe, R. (2010). Current evidence for the management of rheumatoid arthritis with glucocorticoids: a systematic literature review informing the EULAR recommendations for the management of rheumatoid arthritis. Annals of the Rheumatic Diseases, 69(6), 10101014. 10.1136/ard.2009.127332 https://doi. org/10.1136/ard.2009.127332

34. Gossec, L., Chauvin, P., Hudry, C., Poussière, M., de Chalus, T., Saulot, V., Berenbaum, F. (2016). No title. Thu0620 Gender, Disease Activity, Anxiety and Depression Levels are related to the Levels of Fears of Patients with Rheumatoid Arthritis or Axial Spondyloarthritis: A Cross-Sectional Study of 672 Patients, https://doi.org/10.1136/ annrheumdis-2016-eular.2151

35. Grigor, C., Capell, H., Stirling, A., McMahon, A. D., Lock, P., Vallance, R., Kincaid, W. (2004). Effect of a treatment strategy of tight control for rheumatoid arthritis (the TICORA study): a single-blind randomised controlled trial. The Lancet, 364(9430), 263-269. https:// doi.org/10.1016/S0140-6736(04)16676-2
36. Grime, J., Richardson, J. C. \& Ong, B. N. (2010). Perceptions of joint pain and feeling well in older people who reported being healthy: a qualitative study. The British Journal of General Practice: The Journal of the Royal College of General Practitioners, 60(577), 597 603. 10.3399/bjgp10X515106 https://doi. org/10.3399/bjgp10X515106

37. Harriss, D. J. \& Atkinson, G. (2015). Ethical standards in sport and exercise science research: 2016 update. Int J Sports Med, 36(14), 1121-1124. https://doi. org/10.1055/s-0035-1565186

38. Hart, L. E. (1994). Exercise and soft tissue injury. Bailliere's Clinical Rheumatology, 8(1), 137-148. https://doi.org/10.1016/ S0950-3579(05)80228-6

39. Hashkes, P. J., Balistreri, W. F., Bove, K. E., Ballard, E. T. \& Passo, M. H. (1997). The longterm effect of methotrexate therapy on the liver in patients with juvenile rheumatoid arthritis. Arthritis \& Rheumatism, 40(12), 2226-2234. https://doi.org/10.1002/art.1780401218

40. Hewlett, S., Sanderson, T., May, J., Alten, R., Bingham III, C. O., Cross, M., Bartlett, S. J. (2011). ,I'm hurting, I want to kill myself': rheumatoid arthritis flare is more than a high joint count-an international patient perspective on flare where medical help is sought. Rheumatology, 51(1), 69-76. https:// doi.org/10.1093/rheumatology/keq455

41. Hoes, J. N., Jacobs, J. W., Buttgereit, F. \& Bijlsma, J. W. (2010). Current view of glucocorticoid co-therapy with DMARDs in rheumatoid arthritis. Nature Reviews Rheumatology, 6(12), 693. https://doi. org/10.1038/nrrheum.2010.179

42. Hootman, J. M., Macera, C. A., Ham, S. A., Helmick, C. G. \& Sniezek, J. (2003). Physical activity levels among the general US adult population and in adults with and without arthritis. Arthritis Care \& Research, 49(1), 129135. https://doi.org/10.1002/art.10911

43. Hutchinson, D., Shepstone, L., Moots, R., Lear, J. T. \& Lynch, M. P. (2001). Heavy cigarette smoking is strongly associated with rheumatoid arthritis (RA), particularly in patients without a family history of RA. Annals of the Rheumatic Diseases, 60(3), 223227. https://doi.org/10.1136/ard.60.3.223 
44. Janssen, I. \& LeBlanc, A. G. (2010). Systematic review of the health benefits of physical activity and fitness in school-aged children and youth. International Journal of Behavioral Nutrition and Physical Activity, 7(1), 40. https://doi. org/10.1186/1479-5868-7-40

45. Jari, S. \& Noble, J. (2001). Meniscal tearing and rheumatoid arthritis. The Knee, 8(2), 157-158. https://doi.org/10.1016/ S0968-0160(00)00077-6

46. Jennings, F., Lambert, E. \& Fredericson, M. (2008). Rheumatic diseases presenting as sports-related injuries. Sports Medicine, 38(11), 917-930. https://doi. org/10.2165/00007256-200838110-00003

47. Kahn, P. (2009). Juvenile idiopathic arthritis: current and future therapies. Bulletin of the NYU Hospital for Joint Diseases, 67(3), 291.

48. Kahn, P. J. (2013). Juvenile Idiopathic Arthritis. Bulletin of the Hospital for Joint Diseases, 71(3), 194-199.

49. Knittle, K. P., De Gucht, V., Hurkmans, E. J., Vlieland, T. P., Peeters, A. J., Ronday, H. K. \& Maes, S. (2011). Effect of self-efficacy and physical activity goal achievement on arthritis pain and quality of life in patients with rheumatoid arthritis. Arthritis Care \& Research, 63(11), 1613-1619. https://doi. org/10.1002/acr.20587

50. Kvrgic, Z., Asiedu, G. B., Crowson, C. S., Ridgeway, J. L. \& Davis, J. M. (2017). „Like No One Is Listening to Me": A Qualitative Study of Patient-Provider Discordance Between Global Assessments of Disease Activity in Rheumatoid Arthritis. Arthritis Care \& Research, https://doi.org/10.1002/ acr.23501

51. Lawrence, R. C., Felson, D. T., Helmick, C. G., Arnold, L. M., Choi, H., Deyo, R. A., Hunder, G. G. (2008). Estimates of the prevalence of arthritis and other rheumatic conditions in the United States: Part II. Arthritis \& Rheumatology, 58(1), 26-35. https://doi.org/10.1002/art.23176

52. Luime, J. J., Colin, E. M., Hazes, J. M. \& Lubberts, E. (2010). Does anti-mutated citrullinated vimentin have additional value as a serological marker in the diagnostic and prognostic investigation of patients with rheumatoid arthritis? A systematic review. Annals of the Rheumatic Diseases, 69(2), 337344. 10.1136/ard.2008.103283 https://doi. org/10.1136/ard.2008.103283

53. Lundkvist, J., Kastäng, F. \& Kobelt, G. (2008). The burden of rheumatoid arthritis and access to treatment: health burden and costs. The European Journal of Health Economics, 8(2), 49-60. https://doi.org/10.1007/s10198-007-0088-8

54. Maron, B. J., Araujo, C. G., Thompson, P. D., Fletcher, G. F., de Luna, A. B., Fleg, J. L., American Heart Association Committee on Exercise, Cardiac Rehabilitation, and Prevention. (2001). Recommendations for preparticipation screening and the assessment of cardiovascular disease in masters athletes: an advisory for healthcare professionals from the working groups of the World Heart Federation, the International Federation of Sports Medicine, and the American Heart Association Committee on Exercise, Cardiac Rehabilitation, and Prevention. Circulation, 103(2), 327-334. https://doi.org/10.1161/01. CIR.103.2.327

55. Maron, B. J., Chaitman, B. R., Ackerman, M. J., Bayes de Luna, A., Corrado, D., Crosson, J. E., Councils on Clinical Cardiology and Cardiovascular Disease in the Young. (2004). Recommendations for physical activity and recreational sports participation for young patients with genetic cardiovascular diseases. Circulation, 109(22), 2807-2816. 10.1161/01. CIR.0000128363.85581.E1 https://doi. org/10.1161/01.CIR.0000128363.85581.E1

56. Maska, L., Anderson, J. \& Michaud, K. (2011). Measures of functional status and quality of life in rheumatoid arthritis: Health Assessment Questionnaire Disability Index (HAQ), Modified Health Assessment Questionnaire (MHAQ), Multidimensional Health Assessment Questionnaire (MDHAQ), Health Assessment Questionnaire II (HAQ-II), Improved Health Assessment Questionnaire (Improved HAQ), and Rheumatoid Arthritis Quality of Life (RAQoL). Arthritis Care \& Research, 63(S11) https://doi.org/10.1002/ acr. 20620

57. Matcham, F., Ali, S., Irving, K., Hotopf, M. \& Chalder, T. (2016). Are depression and anxiety associated with disease activity in 
rheumatoid arthritis? A prospective study. BMC Musculoskeletal Disorders, 17(1), 155. https://doi.org/10.1186/s12891-016-1011-1

58. Matcham, F., Norton, S., Scott, D. L., Steer, S. \& Hotopf, M. (2015). Symptoms of depression and anxiety predict treatment response and long-term physical health outcomes in rheumatoid arthritis: secondary analysis of a randomized controlled trial. Rheumatology, 55(2), 268-278. https://doi. org/10.1093/rheumatology/kev306

59. Merrill, J. T., Neuwelt, C. M., Wallace, D. J., Shanahan, J. C., Latinis, K. M., Oates, J. C., Hsieh, H. (2010). Efficacy and safety of rituximab in moderately-to-severely active systemic lupus erythematosus: the randomized, double-blind, phase II/III systemic lupus erythematosus evaluation of rituximab trial. Arthritis \& Rheumatology, 62(1), 222-233. https://doi.org/10.1002/art.27233

60. Metin, Z. G. \& Ozdemir, L. (2016). The effects of aromatherapy massage and reflexology on pain and fatigue in patients with rheumatoid arthritis: a randomized controlled trial. Pain Management Nursing, 17(2), 140-149. https:// doi.org/10.1016/j.pmn.2016.01.004

61. Minnock, P., McKee, G., Kelly, A., Carter, S. C., Menzies, V., O’Sullivan, D., van Eijk Hustings, Y. (2018). Nursing sensitive outcomes in patients with rheumatoid arthritis: A systematic literature review. International Journal of Nursing Studies, 77, 115129. S0020-7489(17)30212-2 https://doi. org/10.1016/j.ijnurstu.2017.09.005

62. Nishimura, K., Sugiyama, D., Kogata, Y., Tsuji, G., Nakazawa, T., Kawano, S., Kuntz, K. M. (2007). Meta-analysis: diagnostic accuracy of anti-cyclic citrullinated peptide antibody and rheumatoid factor for rheumatoid arthritis. Annals of Internal Medicine, 146(11), 797-808. https://doi.org/10.7326/0003-4819-146-11200706050-00008

63. Osterweis, M., Kleinman, A. \& Mechanic, D. (1987). Illness behavior and the experience of pain.

64. Patel, D. N., \& Strauss, E. J. (2015). Alternative therapeutic modalities in sports medicine. Bulletin of the NYU Hospital for Joint Diseases, 73(2), 122.

65. Pelliccia, A., Zipes, D. P. \& Maron, B. J.
(2008). Bethesda Conference\# 36 and the European Society of Cardiology Consensus Recommendations revisited: a comparison of US and European criteria for eligibility and disqualification of competitive athletes with cardiovascular abnormalities. Journal of the American College of Cardiology, 52(24), 1990-1996. https://doi.org/10.1016/j. jacc.2008.08.055

66. Philpott, J., Houghton, K. \& Luke, A. (2010). Physical activity recommendations for children with specific chronic health conditions: Juvenile idiopathic arthritis, hemophilia, asthma and cystic fibrosis. Paediatrics \& Child Health, 15(4), 213-218. https://doi. org/10.1093/pch/15.4.213

67. Pincus, T., Yazici, Y. \& Bergman, M. J. (2009). Patient questionnaires in rheumatoid arthritis: advantages and limitations as a quantitative, standardized scientific medical history. Rheumatic Diseases Clinics of North America, 35(4), 735-43, vii. 10.1016/j.rdc.2009.10.009 https://doi.org/10.1016/j.rdc.2009.10.009 https://doi.org/10.1016/j.rdc.2009.10.007

68. Pincus, T., Yazici, Y. \& Bergman, M. (2005). Development of a multi-dimensional health assessment questionnaire (MDHAQ) for the infrastructure of standard clinical care. Clinical and Experimental Rheumatology, 23(5), S19.

69. Pincus, T., Sokka, T., \& Kautiainen, H. (2005). Further development of a physical function scale on a multidimensional health assessment questionnaire for standard care of patients with rheumatic diseases. Journal of Rheumatology, 32(8), 1432-1439.

70. Pincus, T., Swearingen, C. \& Wolfe, F. (1999). Toward a multidimensional Health Assessment Questionnaire (MDHAQ): assessment of advanced activities of daily living and psychological status in the patientfriendly health assessment questionnaire format. Arthritis \& Rheumatology, 42(10), 2220-2230. https://doi.org/10.1002/1529$0131(199910) 42: 10<2220:$ : A I D ANR26>3.0.CO;2-5

71. Pincus, T., Yazici, Y. \& Bergman, M. (2007). A practical guide to scoring a Multi-Dimensional Health Assessment Questionnaire (MDHAQ) and Routine Assessment of Patient Index 
Data (RAPID) scores in 10-20 seconds for use in standard clinical care, without rulers, calculators, websites or computers. Best Practice \& Research Clinical Rheumatology, 21(4), 755-787. https://doi.org/10.1016/j. berh.2007.02.006 https://doi.org/10.1016/j. berh.2007.02.005

72. Pollard, L., Choy, E. H. \& Scott, D. L. (2005). The consequences of rheumatoid arthritis: quality of life measures in the individual patient. Clinical and Experimental Rheumatology, 23(5), S43.

73. Ravelli, A., \& Martini, A. (2007). Juvenile idiopathic arthritis. The Lancet, 369(9563), 767-778. https://doi.org/10.1016/ S0140-6736(07)60363-8

74. Reiner, M., Niermann, C., Jekauc, D. \& Woll, A. (2013). Long-term health benefits of physical activity-a systematic review of longitudinal studies. BMC Public Health, 13(1), 813. https://doi.org/10.1186/1471-2458-13-813

75. Risgaard, B., Winkel, B. G., Jabbari, R., Glinge, C., Ingemann-Hansen, O., Thomsen, J. L., Tfelt-Hansen, J. (2014). Sports-related sudden cardiac death in a competitive and a noncompetitive athlete population aged 12 to 49 years: data from an unselected nationwide study in Denmark. Heart Rhythm, 11(10), 1673-1681. 10.1016/j.hrthm.2014.05.026 https://doi.org/10.1016/j.hrthm.2014.05.026

76. Salaffi, F., Carotti, M., Gasparini, S., Intorcia, M. \& Grassi, W. (2009). The health-related quality of life in rheumatoid arthritis, ankylosing spondylitis, and psoriatic arthritis: a comparison with a selected sample of healthy people. Health and Quality of Life Outcomes, 7(1), 25. https://doi. org/10.1186/1477-7525-7-25

77. Singh, J. A., Furst, D. E., Bharat, A., Curtis, J. R., Kavanaugh, A. F., Kremer, J. M., . . . Beukelman, T. (2012). 2012 Update of the 2008 American College of Rheumatology recommendations for the use of diseasemodifying antirheumatic drugs and biologic agents in the treatment of rheumatoid arthritis. Arthritis Care \& Research, 64(5), 625-639. https://doi.org/10.1002/acr.21641

78. Smolen, J. S., Van Der Heijde, Désirée MFM, St Clair, E. W., Emery, P., Bathon, J. M., Keystone, E., Baker, D. (2006). Predictors of joint damage in patients with early rheumatoid arthritis treated with high-dose methotrexate with or without concomitant infliximab: results from the ASPIRE trial. Arthritis \& Rheumatology, 54(3), 702-710. https://doi. org/10.1002/art.21678

79. Sokka, T., Hakkinen, A., Krishnan, E. \& Hannonen, P. (2004). Similar prediction of mortality by the health assessment questionnaire in patients with rheumatoid arthritis and the general population. Annals of the Rheumatic Diseases, 63(5), 494-497. 10.1136/ard.2003.009530 https://doi. org/10.1136/ard.2003.009530

80. Strand, V., Cohen, S., Crawford, B., Smolen, J. S. \& Scott, D. L. (2004). Patient-reported outcomes better discriminate active treatment from placebo in randomized controlled trials in rheumatoid arthritis. Rheumatology, 43(5), 640-647. https://doi.org/10.1093/ rheumatology/keh 140

81. Swigart, C. R. \& Fishman, F. G. (2017). Hand and wrist pain. Kelley and Firestein's Textbook of Rheumatology (Tenth Edition) (pp. 742755. e3) Elsevier. https://doi.org/10.1016/ B978-0-323-31696-5.00050-4

82. Taibi, D. M. \& Bourguignon, C. (2003). The role of complementary and alternative therapies in managing rheumatoid arthritis. Family \& Community Health, 26(1), 41-52. https://doi. org/10.1097/00003727-200301000-00006

83. Takken, T., Van Brussel, M., Engelbert, R. H., Van Der Net, J., Kuis, W. \& Helders, P. J. (2008). Exercise therapy in juvenile idiopathic arthritis: a Cochrane Review. European Journal of Physical and Rehabilitation Medicine, 44(3), 287-297. R33Y2008N03A0287

84. Tierney, M., Fraser, A. \& Kennedy, N. (2012). Physical activity in rheumatoid arthritis: a systematic review. Journal of Physical Activity and Health, 9(7), 1036-1048. https://doi. org/10.1123/jpah.9.7.1036

85. Van Damme, S., Crombez, G. \& Eccleston, C. (2008). Coping with pain: a motivational perspective. Pain, 139(1), 1-4. 10.1016/j. pain.2008.07.022 https://doi.org/10.1016/j. pain.2008.07.022

86. Van der Goes, Marlies C, Jacobs, J. W. \& Bijlsma, J. W. (2014). The value of glucocorticoid co-therapy in different 
rheumatic diseases-positive and adverse effects. Arthritis Research \& Therapy, 16(2), S2. https:// doi.org/10.1186/ar4686

87. Wachholtz, A. B., Pearce, M. J. \& Koenig, H. (2007). Exploring the relationship between spirituality, coping, and pain. Journal of Behavioral Medicine, 30(4), 311-318. https:// doi.org/10.1007/s10865-007-9114-7

88. Warburton, D. E., Nicol, C. W. \& Bredin, S. S. (2006). Health benefits of physical activity: the evidence. CMAJ: Canadian Medical Association Journal = Journal De L'Association Medicale Canadienne, 174(6), 801-809. 174/6/801 https://doi.org/10.1503/ cmaj.051351

89. Wolfe, F., \& Michaud, K. (2004). Lymphoma in rheumatoid arthritis: the effect of methotrexate and anti-tumor necrosis factor therapy in 18,572 patients. Arthritis \& Rheumatology, 50(6), 1740-1751. https://doi. org/10.1002/art.20311

90. Zaki, J., Davis, J. I. \& Ochsner, K. N. (2012). Overlapping activity in anterior insula during interoception and emotional experience. NeuroImage, 62(1), 493-499. https://doi. org/10.1016/j.neuroimage.2012.05.012

91. Zautra, A. J., Davis, M. C., Reich, J. W., Nicassario, P., Tennen, H., Finan, P., Irwin, M. R. (2008). Comparison of cognitive behavioral and mindfulness meditation interventions on adaptation to rheumatoid arthritis for patients with and without history of recurrent depression. Journal of Consulting and Clinical Psychology, 76(3), 408. https:// doi.org/10.1037/0022-006X.76.3.408 